\title{
Organizational Safety Support Practices and Employee Performance in the Department of Health Services in Makueni County, Kenya
}

\author{
Evalyne Mwongeli Nzuve \\ Master of Arts in Public Administration and Management, \\ Mount Kenya University, Kenya. \\ Jackson Ndolo \\ School of Business and Economics, \\ Mount Kenya University.
}

\begin{abstract}
Many organizations across the globe have adopted occupational safety practices notably organizational safety support in order to improve the working conditions and eventually promote employee performance. However the relationship between organizational safety support and employee performance, has not been well established especially in Kenyan public sector a situation that informed the current study. This study adopted a descriptive research design and targeted an overall 428 employee population. A stratified proportionate sampling was used to obtain a sample of 207 respondents. Structured questionnaires were the main instruments of data collection. Both descriptive and inferential statistics was used to analyze data aided by SPSS. Study results were presented using tables, charts and graphs. The study realized a $72.2 \%$ response rate. Key findings of the study included; the department of health services in the county had embraced various occupational safety practices. Organizational safety support was found to influence $58.8 \%$ of the variations in employee performance. Through safety support practices the department had provided a conducive working environment which in turn had translated to high staff productivity. The findings of the study may find use among public sector managers and policy makers. To uphold research ethics, NACOSTI, MKU ERC and the Governor's Office, Government of Makueni County permission was sought before data was collected.
\end{abstract}

Key Words; Employee commitment, occupational safety, productivity, hazard, working environment

\section{INTRODUCTION}

Occupational safety support has become a topic of interest among researchers and practitioners as institutions seek to make their working environments work - friendly. There has been increasing evidence of significant losses and suffering caused by lack of safe working environment across various sectors of the economy. According to Taderera (2012) occupational safety practices include efforts to promote and maintain the highest standard of workers ' physical, mental and social well-being in all jobs. This has created concerns among managers due to the growing number of work-related deaths and accidents. The current occupational safety situation in Kenya is a matter of growing concern among employers, government, managers, industrialists, workers and other stakeholders. A safe and secure health working enviroment is one of the key responsibilities of the department of health services in Makueni County. There are a variety of interventions that the Makueni county department of Health Services adopts to change employees' lifestyles and non - work behaviors in particular ; prevention of occupational hazards, risk management, support for organizational safety and training practices for first aid. All of these interventions, according to 
Werner (2009) can significantly reduce the many costs associated with workplace injuries, illness, and death. All of this is expected to foster employee performance.

However, a statutory safety and health audit report conducted in 2013 revealed that work related accidents and injuries had increased from 20\% to 30\% especially among technical workers Oluoch (2015). Health care costs have continued to increase, leading to conflict between the needs of the company and those of the employers. While the counties are pushing for increased output, employees on the other hand are demanding protection from hazards and accidents in the place of work. Kahya (2007) claims that unfavorable workplace health conditions decrease the concentration of workers on duties and result in lower worker performance resulting in high costs.

It is evident from existing literature that the employee performance is affected by the occupational safety conditions of the workers, which in turn is influenced by the organizational safety support mechanism but the area has not been adequately covered. These studies have been conducted on the various issues relating to employee performance and occupational safety in different sectors (private and public) in different countries. The study sought to answer the question; Does organizational safety support employee performance?

\section{Employee Performance}

\section{LITERATURE REVIEW}

Employee performance is a concept that aims to achieve results and has a strong relationship with organizational objectives (Khan et al., 2011). Working in a safe and healthy environment increases the level of job satisfaction of the employees. This translates to workforce that is contented, excited about their work and attached to their jobs. Under these circumstances, the performance of the employees will improve because of the cases of reduced absenteeism, punctuality and low turnover rates. One way of empowering employees is by managing employee performance. This can be done by giving employees the opportunity to achieve high productivity by ensuring that they understand their workplace safety thoroughly. There is increasing evidence, according to Lamm, Massey and Perry (2006) that providing a healthy and safe working environment has the potential to increase labor productivity and thus increase business profits. This is because employees focus on their jobs and work in order to meet the company's overall objectives and the organization's mission statement. Employee performance in the department of health services is important because it creates satisfaction for the employees, clients and the organization at large.

Counties in Kenya have taken citizen health seriously with the advent of universal health care amongst the key priority areas in the county strategic development plans. As such Government of Makueni County has put a budget of over Kshs 200,000,000 per year for the next 4 years under the ministry of health. This funds are budgeted and spend by the department of health services with a work force of 228 staff across its 6 subcounties. The county government of Makueni has a total population of about 1 million. To the western part, it borders the county of Kajiado and Taita Taveta to the Southern sides, County of Kitui towards the East and Machakos County towards North. It is divided into 6 Sub Counties namely; Mbooni, Makueni, Kibwezi East, Kaiti, Kilome and Kibwezi West (Kahindi, 2013).

\section{Organization Safety Support}

Organizational support as perceived by the reciprocity principle ensures that employees work for the organization's benefit. It means employees are grateful because they feel the organization is committed to their safety. This will result in increased efforts by workers in 
favor of achieving the goals of the organizations. A wellness program is an active process of becoming aware of a more successful Robinson existence (2006) and making choices. As Rhoades et al. (2001) observed, there is more to be appreciated, approved and recognized by the association between perceived organizational support and high performance in workers. Therefore, they will be more productive if employees feel the organization. McLain and Jarrell (2007) suggested that perceived safety and compatibility requirements for manufacturing had a positive effect on safe working behavior and reduced interference with safety hazards performing other tasks. Accordingly, investments in health practices based on the theory of social exchange and the principle of reciprocity result in health and well-being for employees. These investments are intended to reduce or eliminate inappropriate workplace design, illstructured jobs, inconsistencies between job requirements and the ability of workers Otherwise if workers perceive that the organization is keen on enabling a safe work environment. They are going to have a higher performance level. This is because such workers are internalizing organizational values and standards with greater affective commitment, participation, and loyalty as Gyekye and Salminen (2007) observed.

The study sought to establish the influence of organization safety support on employee performance. This was achieved by reviewing the effect of employee wellness, sharing of safety information and the organizations commitment on employee productivity, staff turnover and achievement of set objectives. The study was investigating whether there are any employee wellness programs and the effect of these programs on staff turnover and improved employee productivity. In addition, the study established if and how the management of the organization passes or share safety information with the employees and how this affects productivity, staff turnover and achievement of objectives. Lastly the study determined the level of organization commitment towards the safety of employees. The study established how the level of organizational commitment affects the level of employee productivity, staff turnover and ability to achieve the set objectives. Based on the above the following was hypothesized

$\boldsymbol{H}_{1:}$ Organizational safety support positively influences employee performance

\section{METHODOLOGY}

Descriptive survey research design was adopted for this study. The study area was department of health Makueni County and targeted 428 staffs who were involved directly with the implementation of safety policy, medical personnel; doctors, clinical officers, and nurses. A sample of 207 staff was calculated using the Slovin formulae while stratified proportionate sampling method was used to obtain the sample since the population was not homogeneous but classified in stratus of professions as shown in table 1 ;

Table 1: Sample Distribution at Department of Health Services, Makueni County

\begin{tabular}{lccc}
\hline Section & Population & Proportionate \% & Sample \\
Medical doctors & 67 & 15.6 & 33 \\
Nurses & 246 & 57.6 & 119 \\
Radiotherapy & 13 & 3.0 & 6 \\
Support staff & 102 & 23.8 & 49 \\
Total & $\mathbf{4 2 8}$ & $\mathbf{1 0 0}$ & $\mathbf{2 0 7}$ \\
\hline
\end{tabular}

Source: Researcher, (2018)

The researcher sought authorization from Department of health services management, Makueni County before administering the questionnaires. This was accompanied by the letter obtained from Mount Kenya University indicating the researcher's approval to collect the data. In addition, a research permit from NACOSTI was sought to authorize data collection. Questionnaires were then given to the various respondents and collected after a period of two weeks. 


\section{Demographics of Respondents}

\section{ANALYSIS OF RESULTS}

The study realised a response rate of $77.8 \%$. According to Dixon (2012), a response rate of $50 \%$ and above is adequate to draw conclusion on the study phenomenon. Gender characteristic of the respondents indicated that, Females were the majority represented by $50 \%$, Males were $49 \%$ of the respondents while $1 \%$ did not indicate their gender. Unlike other professions dominated by men the medical filed seems to be the opposite, a not so exciting finding for the boy child who seems to lag behind matters empowerment is concerned. In relation to this study, it was deduced that all gender categories took part in the study and therefore, findings obtained in this study were not biased to any gender.

Figure 3: Percentage of respondents by Gender

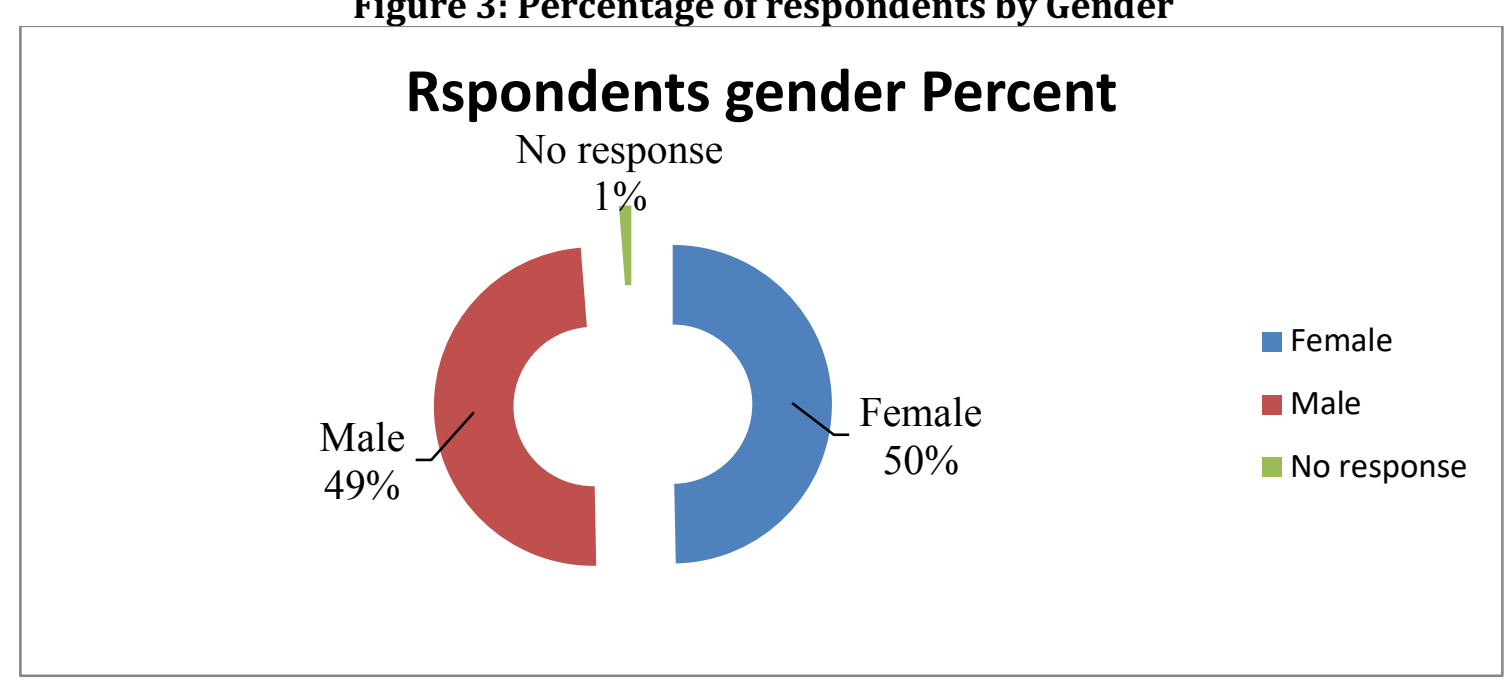

Source: Researcher, (2019)

Diploma holders were the majority of the work force with $42.2 \%$ as shown in Table 4 . Those with undergraduate degree accounted for $28.0 \%$, certificate holders were $19.3 \%$ while $9.9 \%$ had post graduate qualification while less than $1 \%$ did not respond as shown in Table 2 . These findings indicate that respondents in this study had high education qualification and thus they were knowledgeable and agile to grasp the concepts of organisational safety support and employee performance.

Table 2: Distribution of Respondents by level of Qualification

\begin{tabular}{lcc}
\hline & Frequency & Percentage \\
\hline Certificate & 31 & 19.3 \\
Diploma & 68 & 42.2 \\
Undergraduate & 45 & 28.0 \\
Postgraduate & 16 & 9.9 \\
No response & 1 & 0.6 \\
N & 161 & 100.0 \\
\hline
\end{tabular}

Source: Researcher, (2019)

Majority, 55\% of the respondents were PROSAK members, 27\% KMPDU, 7\% post exposure, prophylaxis, $6 \%$ nursing council of Kenya, $3 \%$ nursing council while $2 \%$ were KNUN members respectively. This is an indication that the county medical staff are aware of the importance of professional membership to this bodies hence possess the perquisite knowledge and skills to participate in this study. 
Figure 1: Professional Bodies

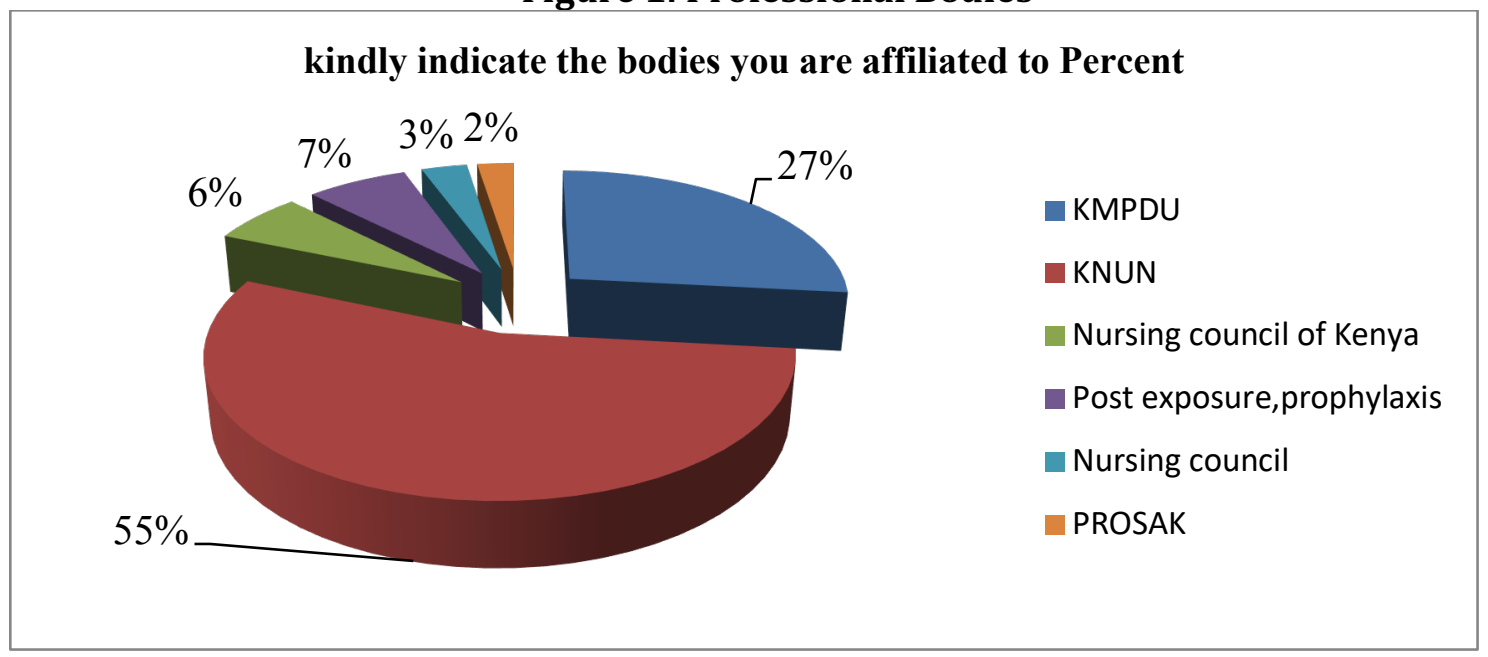

Source: Researcher, (2019)

\section{Functions of Occupational Safety Department in Makueni County}

Majority, 61\% of the respondents agreed that their county had established an occupational safety department, $38 \%$ did not agree with $1 \%$ of the respondents not responding. This is an indication that although majority was aware of the occupational safety department a big percentage did not know of its existence. This justifies the researcher's choice of the county for this study. Majority, 27.3\% listed employee protection, 14.9\% Occupational safety practices, $11.2 \%$ Training on hazard prevention, $11.2 \%$ Promoting safety of employees , $11.2 \%$ Provision of safety equipment, $8.7 \%$ Staff protection, $8.7 \%$ Risk management and $6.8 \%$ Prevention programs respectively. This is an indication that the department had embraced a number of occupational safety practices in line with various regulations and health and safe working environment government directives.

Majority, $49.1 \%$ of the respondents listed to wear protective gear, $13 \%$ to be aware of fire assembly points, 9.3\% embraced ethical practices, $6.8 \%$ observed waste segregation utilization, $5.6 \%$ had embraced first aid practices, $5.0 \%$ had put into place risk mitigation measures, $4.3 \%$ sterilized equipment's or tools, $4.3 \%$ used personal protective and $2.5 \%$ identified open forums as means of promoting safety at work place. This is an indication that the respondents were aware of the of the occupational practices and had embraced them so as to have a safe working environment.

\section{Organizational Safety Support and Employee Performance}

In this section respondents were asked to comment on various organization safety support; employee wellness programs and information sharing policy in relation to employee performance as indicated on Table 3. Majority, 46.5\% agreed of the respondents, 35.4\% strongly agreed, $13.7 \%$ neutral, $2.5 \%$ disagreed and $1.9 \%$ strongly agreed that the department had implemented employee wellness programs. This is an indication that the department management embraces employees' wellness programs. The employee wellness programs in the department influences employee productivity as indicated by $59.0 \%$ of the respondents agreed, $33.5 \%$ strongly agreed, $5.0 \%$ were neutral, $1.9 \%$ strongly disagreed while no respondent disagreed.

The department safety information sharing policy has influenced achievement of set goals by the employee since majority, 50.9\% agreed, 31.1\% strongly agreed, $14.9 \%$ were neutral, $1.9 \%$ and $1.2 \%$ of the respondents strongly disagreed and disagreed respectively. This is an indication that information sharing influences positively employee performance. 
Table 3: Organizational Safety support and Employee Performance

\begin{tabular}{|c|c|c|c|c|c|c|}
\hline Statement: & $\begin{array}{l}\text { Strongly } \\
\text { Agree }\end{array}$ & Agree & Neutral & Disagree & $\begin{array}{r}\text { Strongly } \\
\text { Disagree }\end{array}$ & Percentage \\
\hline \multicolumn{7}{|c|}{ Percentage } \\
\hline $\begin{array}{l}\text { 1. Our department has } \\
\text { implemented employee } \\
\text { wellness programs }\end{array}$ & 35.4 & 46.5 & 13.7 & 2.5 & 1.9 & 100.0 \\
\hline $\begin{array}{l}\text { 2. The employee wellness } \\
\text { programs in the department } \\
\text { influences employee } \\
\text { productivity }\end{array}$ & 33.5 & 59.0 & 5.0 & --- & 1.9 & 100.0 \\
\hline $\begin{array}{l}\text { 3. The department safety } \\
\text { information sharing policy } \\
\text { has influenced achievement } \\
\text { of set goals by the employee }\end{array}$ & 31.1 & 50.9 & 14.9 & 1.2 & 1.9 & 100.0 \\
\hline
\end{tabular}

Source: Researcher, (2019)

\section{Regression Analysis}

This study sought to analyse the influence of organisational safety support on employee performance at the department of health, Makueni County Kenya. Model summary in regression analysis points out to the results of goodness fit. $\mathrm{R}$ squared is the coefficient of determination. In this study, the coefficient of determination was 0.588 . This indicates that $58.8 \%$ of variation in employee performance is explained by organisational safety support.

Table 4: Model Summary Model Summary

\begin{tabular}{|l|r|r|r|r|}
\hline Model & \multicolumn{1}{|c|}{$\mathrm{R}$} & \multicolumn{1}{c|}{ R Square } & Adjusted R Square & \multicolumn{2}{c|}{$\begin{array}{c}\text { Std. Error of the } \\
\text { Estimate }\end{array}$} \\
\hline 1 & $.767 \mathrm{a}$ & .588 & .577 & .42039 \\
\hline
\end{tabular}

a. Predictors: (Constant), OSSEP

Source: Researcher, (2019)

Analysis of variance describes the significance of the overall model. From the results, the $\mathrm{F}$ statistic was $54.927 \%$. P value was 0.00 smaller than the critical $\mathrm{p}$ value 0.05 . Therefore, the model was significant at $95 \%$ confidence level.

Table 5: ANOVA

ANOVAa

\begin{tabular}{|ll|r|r|r|r|r|}
\hline Model & & Sum of Squares & \multicolumn{1}{c|}{$\mathrm{df}$} & Mean Square & F & Sig. \\
\hline \multirow{3}{*}{1} & Regression & 38.828 & 4 & 9.707 & 54.927 & $.000^{\mathrm{b}}$ \\
& Residual & 27.216 & 154 & .177 & & \\
& Total & 66.044 & 158 & & & \\
\hline
\end{tabular}

a. Dependent Variable: EP

b. Predictors: (Constant), OSSEP

Source: Researcher, (2019)

Constant for the regression model in this study had a coefficient of 0.83 significant at $95 \%$ confidence level ( $\mathrm{p}$ value $=0.001$ less than 0.05). Organizational Safety Support had a coefficient of 0.262 denoting a positive correlation with employee performance. This relationship was significant at $95 \%$ confidence level $(\mathrm{P}$ value $=0.002)$. Hence the study hypothesis $\mathrm{H}_{1}$ Organizational safety support positively influences employee performance was accepted 
Table 7: Coefficients of Measurements Coefficients ${ }^{\mathrm{a}}$

\begin{tabular}{|cc|c|c|c|c|c|}
\hline \multicolumn{2}{|l|}{ Model } & \multicolumn{2}{|c|}{$\begin{array}{c}\text { Unstandardized } \\
\text { Coefficients }\end{array}$} & $\begin{array}{c}\text { Standardized } \\
\text { Coefficients }\end{array}$ & \multirow{2}{*}{$\mathrm{t}$} & \multirow{2}{*}{ Sig. } \\
\cline { 3 - 5 } & \multicolumn{2}{|c|}{$\mathrm{B}$} & Std. Error & Beta & & \\
\hline \multirow{2}{*}{1} & (Constant) & .830 & .239 & & 3.478 & .001 \\
& OSSEP & .244 & .077 & .268 & 3.188 & .002 \\
\hline
\end{tabular}

a. Dependent Variable: EP

\section{Source: Researcher, (2019)}

The study model was of the form: $Y=\alpha+\beta X+\mu$. Where; Y= Employee Performance, $\alpha=$ is the constant, $X=$ Organizational safety support, $\mu=$ is the unpredictable random element or error term and $\beta$ is coefficients of $\mathrm{X}$. Based on the significant variables, the fitted model became; $\mathrm{Y}=$ $0.83+0.268 \mathrm{X}+\mu$

\section{DISCUSSION AND CONCLUSION}

Majority of respondents agreed that their county had established an occupational safety department while slightly more than a third disagreed. This is an indication that though majority were aware of the occupational safety department a big percentage did not know of its existence. Putting on protective gear was the most embraced method of occupational safety. Majority, 59.0\% of the respondents agreed that employee performance has improved due to, organizational support, conformance to safety rules and departments favorable working environment. This findings is in agreement with Shannon et al (2001) who suggest that safety in the workplace play an essential role and grant the right to a healthy, safe and legal place of work. Employees working in a healthy and safe workplace are strong psychologically, which help them improve efficiency and job performance.

In conclusion the department of health Makueni County had put into place employee wellness programs, budgetary support and information sharing policy in relation to organizational safety support. The institution was also found to be compliant with the health and safety regulations both at national and international levels. . This in turn has promoted employee performance since they can feel the county's top most leadership support on their occupational safety promotion. The study suggests further studies on other occupational safety practices and how they affect employee performance as well as in other organisations.

\section{References}

Abuga, G. (2012). A Case Study on the Effects of Occupational Health and Safety Programs on Organizational Effectiveness, Unpublished, Kenyatta University.

GoK (2010). Constitution 2010. Government printer. Nairobui. Kenya

Gyekye, \& Salminen, S. (2007). Workplace safety perceptions and perceived organizational support: do supportive perceptions influence safety perceptions?. International Journal of Occupational Safety and Ergonomics, 13(2), 189-200.

Jelimo M. S(2007), The Effects of Occupational Health and Safety on Employee Productivity (Descriptive Study), Unpublished, Moi University, Kenya.

Kahindi, H. S. (2013). Institutionalization of devolved governance strategy by county governments in Kenya Doctoral dissertation, University of Nairobi.

Kahya, E. (2007). The effects of job characteristics and working conditions on job performance. International Journal of Industrial Ergonomics, 37(6), 515-523.

Kothari, B. L. (2007). Research methodology: Tools and techniques. ABD Publishers.

Makueni County Government, (2018) Employee master list 
Mberia (2007) A Survey on Occupational Safety and Health Programs Adopted by Operatin in. Unpublished, Nairobi University Kenya

McLain, D. L., \& Jarrell, K. A. (2007). The perceived compatibility of safety and production expectations in hazardous occupations. Journal of safety Research, 38(3), 299-309.

Mejia (2010). Improving Patient Safety through Medical Alert Management: An Automated Decision Tool to Reduce Alert Fatigue: https://www.researchgate.net/publication/49967686 [accessed Mar 11 2019].

Oluoch, E. O. (2015). Effect of occupational safety and health programmes on employee performance at Kenya Power Company Limited. An M. Sc thesis, University of Nairobi.

Orodho, A.J. (2003) Essentials of Educational and Social Science Research Methods. Mazola

OSHA. (2016). Occupational Safety and Health Administration. OSHA: United States Department of Labour. USA

Petersen, D. (1996). Neuropsychological correlates of violence and aggression: A review of the clinical literature. Aggression and Violent Behavior, 1(1), 3-25.

Pike A (2000). Tough Targets and Heavy Penalties: Financial Times: Business Health and Safety. London Printers, UK

Rhoades et al. (2001). Affective commitment to the organization: The contribution of perceived organizational support. Journal of Applied Psychology, 86, 825-836.

Slovin, E. (1960). Slovin's formula for sampling technique. Retrieved on January, 30, 2019.

Taderera (2012). The Impact of Economic and Financial Factors on UK Property Performance. Journal of Property Research. London Press. UK

Werner, A. F. (2009). OSH in Argentina. In Elgstrand, K., Petersson, N. F. (Eds.), OSH for development. Stockholm, Sweden: Royal Institute of Technology 